\title{
вM] Global Health Why we should never do it: stigma as a behaviour change tool in global health
}

\author{
Alexandra Brewis (D), Amber Wutich
}

To cite: Brewis A, Wutich A. Why we should never do it: stigma as a behaviour change tool in global health. BMJ Global Health 2019;4:e001911. doi:10.1136/ bmjgh-2019-001911

Handling editor Seye Abimbola

Received 13 August 2019 Revised 18 September 2019 Accepted 21 September 2019

Check for updates

(C) Author(s) (or their employer(s)) 2019. Re-use permitted under CC BY-NC. No commercial re-use. See rights and permissions. Published by BMJ.

School of Human Evolution and Social Change, Arizona State University, Tempe, Arizona, USA

Correspondence to Dr Alexandra Brewis; ALEX.BREWIS@ASU.EDU
One of the greatest public health successes of the last half of the 20th century was the rapid decline in smoking rates in higher income countries. Levels plummeted in the wake of vilifying campaigns that stigmatised not just tobacco but its users. As historian Allan Brandt described it, "What is fragrant became foul; what is attractive became repulsive; a public behavior became virtually private... American smokers became pariahs in a powerful moral tale of risk and responsibility-objects of scorn and hostility clustered around the doors of buildings'. ${ }^{1}$ Such stigma-based tactics can motivate people to profound and difficult behaviour change, leveraging the very human desire to feel valued by others. By stigma, we mean the process of attaching shame and disgust to traits that cause people to be pushed down and out from society. ${ }^{2}$ Stigma is also often a preferred public health tool, too, when it can substitute for other approaches that require long-term drug discovery efforts, costly hardware or specialised facilities to deliver. It relies, rather, mainly on health education with negative messaging.

Yet, we must also look at the downsides of this use of what is a seemingly effective tool. Stigma is widely recognised in global health as a socially constructed barrier to effective healthcare. Those with lung cancer, for example, may avoid seeking a timely diagnosis or fail to disclose illness to others because of the felt stigma associated with the disease, leading to worse prognoses. ${ }^{34}$ But the process of stigmatisation has a social injustice dimensions too. Now that smoking is widely stigmatised in the advanced economies, it is most prevalent among those with the least power-the young, the poor, the less-educated and those living with mental illness. It has become highly classed within the USA, for example, and this then further exacerbates stigma towards smokers. ${ }^{3}$

It is in these margins of healthcare systems that the costs of those 'successful' stigma tactics become apparent. These already-burdened

\section{Summary box}

Stigma is used as a tool for motivating health behaviour change, often effective at budging otherwise hard-to-shift behaviour.

- Shame-induced stigma most damages those already vulnerable, reinforcing health disparities.

- Global health use of shaming tactics can inadvertently worsen health-damaging stigma, especially for those with the least power.

- These effects, that drive additional health disparities and suffering, are difficult to prevent.

- Ethically and practically, stigma should never be deployed as a global health tool because the effects are often both unavoidable and invisible to outsiders.

lower income populations are now the dually targeted by both stigmatising antismoking campaigns and the advertising of multinational tobacco companies. In this way, stigma use can inadvertently create additional suffering, but also ultimately create or reinforce population health disparities. ${ }^{56}$ And here is the outline of a problem that global health is not directly addressing, but must: its own role in promoting the spread and entrenchment of health-damaging stigmas in the most vulnerable populations.

Of all the domains in global health, the power of stigma (and its helpmates, shame and disgust) has been most widely systematically and widely deployed in international sanitation interventions. First introduced in the 1990s in South Asia but spreading globally fast, community-led approaches to total sanitation (CLTS or Community Approaches to Sanitation (CATS) ) uses disgust to 'trigger' a desire to improve hygiene behaviours, buttressed by social shaming to maintain it. The basic UNICEF manual on how to create open defecation free (ODF) communities lays out general steps (p12-14). ${ }^{7}$

Step 1: identify and train local facilitators to guide community activities and proclaim the village as seeking $100 \%$ ODF certification. 
Step 2: use the triggering process 'to generate a sense of shame and disgust, which in turn mobilizes community members to take immediate action to end open defecation'. The trigger moment is members 'collectively realizing that open defecation amounts to eating each other's feces'. Some recommended triggering activities include the 'walk of shame' to identify the households doing the most open defecation.

Step 3: guide community members to develop low-cost latrine designs and a sanitation plan for their village, using their own labour and material resources to immediately begin latrine construction.

Step 4: identify and empower 'natural leaders'-those locally most enthused about the intervention-to 'advocate' for follow through.

Step 5: "[T] hree to six months after a community has made its initial ODF declaration, it can become certified as open defecation free"

The metric of success herein is absence of outdoor defecation. None of the steps outlined for CLTS involve considering, let alone tracking, what happens to the newly introduced shame for people unable to adopt the new behaviours. They are the most marginal: those without land, labour, money or physical ability to build their own sanitation facilities.

The most powerful ethnographic description of the damaging wake of CLTS-induced stigma is from Subornokhuli village, Bangladesh. ${ }^{8}$ Based on participant observation and extended interviews, in the wealthier households CLTS worked well. People embraced sanitation improvement. But once norms towards open defecation shifted in the wealthier sectors of the village, what of the already most vulnerable families who could not afford the builds? They became highly shamed, to the point of abject distress and searing social rejection. Consider the local primary school teacher, talking of how she repeatedly deployed shaming of those children without household toilets in her class lessons designed to advance the campaign:

\footnotetext{
During one session we called one boy student in the front and asked him to take off his pant. As he was hesitating, we asked him the reason. He replied that it was not proper. Then we told if they considered it improper then how they defecated openly! Didn't they consider it as a shameful act? We found that it helped the student to grasp the issue well. Therefore, we used to follow it often in the sessions (Mahbub, p12). ${ }^{9}$
}

In our own anthropological work, we have identified that people across culturally diverse sites make similarly consistent cognitive connections between disgust reactions and stigmatising the person associated with what disgusts. ${ }^{10}$ This means such efforts as disgust-triggering should be expected to shift a reaction towards to a disgusting object (faeces) onto 'disgusting people'.

In sanitation interventions like CLTS, the shame and stigma production is purposeful. In other domains of global health, the shame is often implicit to health professionals own belief systems. This can be just as damaging. In antiobesity efforts, the shame placed on excess weight is based in cultural ideas about excess weight reflecting unwanted moral traits like being lazy, dirty, stupid, unmotivated and non-compliant. Health professionals tend to stigmatise obese bodies as much or even more than the lay public and seem to generally agree with the idea that a little shame can help motivate healthier behaviours. ${ }^{11}$ This is despite general recognition that those who are poorest are disadvantaged by a relative inability to afford the foods needed to meet healthy eating guidelines. ${ }^{12}$

The systematic ethnographic work of anthropologists in the central Pacific-one of the first world regions to be identified as having extreme population levels of obesity and so targeted with antiobesity campaigns-has shown that stigma-carrying self-blame messages around individual responsibility for weight loss can, over time, breed cynical or ambivalent public reactions to the to the idea of investing effort in weight loss efforts. ${ }^{13}$ But as population-level changes shift obesity from a condition of wealth to one of poverty in the middle and lower income nations, the stigmatized obese body then also become more of a socioeconomic liability. The result: those with larger bodies can then find themselves further marginalised, as they experience additional exclusions in employment, education and other realms. This is not to say that all behaviourchange efforts that promulgate self-blame and shame will necessarily result in such damaging discrimination. Rather, any effects are most likely to emerge where they are both most damaging and least apparent: at the bottom of social and economic hierarchies.

Discussions of the ethics of using stigma as a health promotion tool argue for a 'sweet spot' that maximises the wanted behaviour change while minimising negative effects (eg, Riley et $a l^{14}$ ). This notion can be based the utilitarian proposal that the benefits to many balance the damage to few, contracturalist ideas that the enactment of stigma can be disconnected from low power, or communitarian approaches that suggest the reminder to self-scrutinise that stigma affords is useful at promoting healthy behaviour change. ${ }^{15}$ We disagree, because the effects of stigma are most concentrated in the very contexts of inequality, marginalisation and vulnerability that are a central concern of our global health work. ${ }^{6}$ Blacksher suggests the way forward is reframing public health from its focus on individual responsibility, thus removing personal blame. Then, all interventions are effectively neutralised..$^{15}$ This would certainly help. But it is an unimaginably large and uncertain project that requires shifts in the most fundamental values of neoliberalism. These powerful beliefs about personal accountability are not just pervasive in public policy and health practice, but internalised within the most vulnerable sectors of society as well $\left(\mathrm{eg}\right.$, Sweet $\left.^{16}\right)$. So, in practical terms we rather suggest the following: until there is compelling empirical counter-evidence of primum non nocere, shame-based stigma strategies-even if they ostensibly work to nudge much-needed 
healthier behaviours — should never be deployed as part of the global health toolkit.

Twitter Alexandra Brewis @brewis_alex

Contributors Both authors conceived, wrote and edited the commentary.

Funding The authors have not declared a specific grant for this research from any funding agency in the public, commercial or not-for-profit sectors.

Competing interests None declared.

Patient consent for publication Not required.

Provenance and peer review Not commissioned; externally peer reviewed.

Data availability statement There are no data in this work.

Open access This is an open access article distributed in accordance with the Creative Commons Attribution Non Commercial (CC BY-NC 4.0) license, which permits others to distribute, remix, adapt, build upon this work non-commercially, and license their derivative works on different terms, provided the original work is properly cited, appropriate credit is given, any changes made indicated, and the use is non-commercial. See: http://creativecommons.org/licenses/by-nc/4.0/.

ORCID iD

Alexandra Brewis http://orcid.org/0000-0003-3769-4205

\section{REFERENCES}

1 Brandt AM. The cigarette century: the rise, fall, and deadly persistence of the product that defined America. AZ: Basic Books, 2007.

2 Link BG, Phelan J. Stigma power. Soc Sci Med 2014;103:24-32.

3 Stuber J, Galea S, Link BG. Smoking and the emergence of a stigmatized social status. Soc Sci Med 2008;67:420-30.

4 Chapple A, Ziebland S, McPherson A. Stigma, shame, and blame experienced by patients with lung cancer: qualitative study. BMJ $2004 ; 328$.
5 Hatzenbuehler ML, Phelan JC, Link BG. Stigma as a fundamental cause of population health inequalities. Am J Public Health 2013;103:813-21.

6. Brewis AA, Wutich AL. Lazy, crazy, and disgusting: stigma and the undoing of global health. Baltimore, MD: Johns Hopkins University Press, 2019.

7 UNICEF. Community approaches to sanitation, 2009. Available: https://www.unicef.org/socialpolicy/files/Field_Note_-_Community_ Approaches to Total Sanitation.pdf

8 Mahbub A. Exploring the social dynamics of Community-Led Total Sanitation (CLTS) in Bangladesh: The inclusion of children, women and vulnerable people. In: Mehta L, Movik S, eds. Shit matters: the potential of Community-Led total sanitation. England: Practical Action Publishing, 2013: 39-51.

9 Mahbub A. Social dynamics of CLTS: inclusion of children, women and vulnerable. CLTS conference 1-23, 2008. Available: https:// www.communityledtotalsanitation.org/resource/social-dynamicsclts-inclusion-children-women-and-vulnerable

10 Brewis A, Wutich A, du Bray MV, et al. Community hygiene norm violators are consistently stigmatized: evidence from four global sites and implications for sanitation interventions. Soc Sci Med 2019;220:12-21.

11 Puhl RM, Heuer CA. Obesity stigma: important considerations for public health. Am J Public Health 2010;100:1019-28.

12 Hirvonen K, Bai Y, Headey D. Cost and affordability of the EATLancet diet in 159 countries. Lancet 2019:22.

13 Hardin J, McLennan AK, Brewis A. Body size, body norms and some unintended consequences of obesity intervention in the Pacific Islands. Ann Hum Biol 2018;45:285-94.

14 Riley KE, Ulrich MR, Hamann HA, et al. Decreasing smoking but increasing stigma? anti-tobacco campaigns, public health, and cancer care.. AMA J of Ethics 2017;19.

15. Blacksher E. Public health and social justice: An argument against stigma as a tool of health promotion and disease prevention. In: Major B, Dovidio JF, Link BG, eds. The Oxford handbook of stigma, discrimination, and health.. Oxford University Press, 2018.

16 Sweet E. "Like you failed at life": Debt, health and neoliberal subjectivity. Soc Sci Med 2018;212:86-93. 